\title{
The Effect Of Intellectual Capital On The Financial Performance Of Libyan Banks
}

\author{
Khalad M. S. Alrafadi
}

\begin{abstract}
This study examines intellectual capital (IC) performance of Libyan banks during the period from 2004 to 2010, using value-added intellectual coefficient (VAIC) methodology, and investigates the impact of IC on financial performance. It identifies the IC components that may be the drivers of the traditional indicators of bank success. The results of the study showed that private banks are more concerned with the components of intellectual capital compared to commercial banks and specialized banks. The results also showed that there is a positive relationship between the components of the (VAIC) and the (ROA). The study recommended that Libyan banks should add a post or position to manage intellectual capital in their organizational structures to help structure relevant strategies and policies on how to obtain, utilize and develop the best resources required for intellectual capital.
\end{abstract}

Index Terms - Financial Performance Indicators; IC Performance; Libyan Banks.

\section{INTRODUCTION}

It is widely recognized that with the advent of the knowledge-based economy, traditional sources of competitive advantages that rely on tangible assets have begun to create stable value and maintain competitive advantage and are beginning to disappear [1].

In the new economic era, intellectual capital resources (IC), such as human capital and customer relationships, have become the most important factors for business success and a key factor in maintaining competitive advantage and creating value for companies [2], [3]. Accordingly, the ability to create a competitive advantage and long-term value resides in the effective management of intellectual capital compared to tangible assets. This is very true in knowledge-based industries such as the financial industry such as banking, as the main resources in these industries are intangible and intellectual in nature [3]. According to [4] The efficient use of the integrated information system is crucial for achieving success in the banking sector compared to other industries, stressing that the provision of high-quality services by the bank depends on its investment in the items related to the organization such as its human resources, brand building, systems and operations. although material capital is necessary for the functioning of banks, it is intellectual capital that determines the quality of services provided to clients[5]. Therefore, it becomes necessary for banks to manage intellectual capital as efficiently as possible. This study adopted the Value Added Factor of Intellectual Capital (VAIC) developed by Pulic in 1998 to measure the performance of intellectual capital (IC) for banks in Libya.
This study also investigates whether the intellectual capital and its components influence the measures of financial performance of banks (i.e. return on assets and return on equity) [6]. The banking sector is the most active sector in the Libyan economy, and it plays an active role in the economic development of the country. The Libyan banking sector is one of the main beneficiaries of the government's ongoing efforts to diversify its economy into non-oil sectors. Where, the financial industry plays an important role in the country's progress and economic development. And in this regard, the financial industry usually plays an important role in the progress of a country and its economic development. In this regard, banks as financial intermediaries play a key role in transforming deposits into financial assets [7]. The banking sector as one leading sector in modern economies has also become the criterion for measuring the safety of the national economy of any country [8]. The banking sector in Libya encountered large and very important changes with the installation of a new national payments system, a program which was implemented in 2005 following consultation with the World Bank [9]. This indicates that the banking sector in Libya was previously prohibited and largely restricted, which led to the formation of a closed and unable to compete banking sector. As a result, maintaining a sustainable competitive advantage is crucial for Libyan banks to outperform their competitors. Hence, given the fact that the main resources of banks are intellectual and intangible in nature and that they play the most important role in the value creation process, it is important to explore the efficiency of value creation in the banking sector and to analyze the extent of management of intellectual capital resources. This study contributes greatly to providing Libyan banks with a simple way to understand and evaluate performance, as well as to enhance intellectual capital management. Administrative literature will also help in identifying the potential role of efficiency in the financial performance of Libyan banks, as Libya lacks such research.

The paper unfolds as follows. Section 1 provides an overview of the banking system in Libya, section 2 provides a review of the literature, and section 3 provides an overview of intellectual capital, followed by section 4 on the methodology, data, and variables. Section 5 provides empirical results while section 6 is conclusion.

\section{LITERATURE REVIEW}

In a rapidly changing financial market worldwide, bank regulators; managers; and investors are concerned about how efficiently banks transform their expensive inputs into 
various financial products and services.

Abdulsalam, Al - Qaheri and Al - Khayyat [10]: This study used the value added coefficient of intellectual capital (VAIC), (a model that is widely used to measure the efficiency of intellectual capital) for Kuwaiti banks using data for ten years from 1996 to 2006 . Where, banks were divided into commercial and non-commercial banks. It is lagging behind almost all commercial banks in the years from 2004 to 2006. The results of the customer classification for the year 2006 have been achieved that the best banks are using intellectual value-added capital and results on the basis of the efficiency of human capital are results similar to those in the value-added of capital Intellectual thinking, as are the results of the arrangement based on capital efficiency factor

Abdullah\& Sofian [11]: This study aimed to explore the inclusion of spiritual capital as a new component along with the other three components of intellectual capital (IC) (human capital, structural capital and relationship capital). While, trying to determine the impact of intellectual capital on the performance of listed Malaysian public companies (PLCs). The results revealed that all four components of intellectual capital have a significant positive relationship with the performance of Malaysian companies. Surprisingly, relationship capital has emerged as a component (IC) that has a strong relationship with corporate performance, followed by spiritual capital, structural capital, and human capital. This result indicates that intellectual capital is vital to business success and performance. More importantly, the study found that spiritual capital needs to be taken into account when measuring performance using intellectual capital. Finally, this study suggests that future research should investigate the impact of new intellectual capital on companies 'performance in various sectors such as trade, services, finance, and technology.

Al - Musali \& Ismail [12]: This study examined the performance of intellectual capital (IC) for banks listed in the Kingdom of Saudi Arabia using the methodology of the value added factor of intellectual capital (VAIC), as the study investigated the effect of intellectual capital on financial performance. In addition to defining the IC components that may lead to traditional indicators of bank success. The results of the survey of banks listed in Saudi Arabia during the period from 2008 to 2010 indicated that the performance of (IC) of Saudi banks is low and is positively related to the financial performance indicators of the bank. However, when the VAIC was divided into its components, the relationships between these components and banks' financial performance indicators differed.

Arifian [13]: The aim of this study was to assess the impact of corporate governance and intellectual capital on the financial performance of banking sector companies. The banking sector companies were listed as unit data on the Jakarta Stock Exchange (IDX) for the period 2008-2012. The unit's data consisted of audited financial statements of companies and historical stock price data on the Indonesia Stock Exchange from 2008 to 2012. The companies surveyed were the companies that met the sampling standards (130 companies). Data were analyzed using General Structural Component Analysis (GSCA). The results of the research indicate that corporate governance does not have a significant impact on intellectual capital. Likewise, intellectual capital is of little importance in the area of corporate governance. However, corporate governance and intellectual capital significantly affect the financial performance of the banking sector companies included in (IDX) for the period from 2008 to 2012. This means that any changes in corporate governance and intellectual capital may affect the financial performance of the banking sector companies listed in (IDX).

Onyekwelu, Okoh\& Iyidiobi [14]: This study evaluated the effect of intellectual capital on financial performance of firms in Nigeria using the banking industry. The research used the Value Added Intellectual Coefficient (VAIC) to ascertain the extent that intellectual capital indices affect financial performance of three Nigeria. Data were collected from the published annual financial statements of the three banks and analyzed using regression tool. The study indicated that IC has a positive and significant effect on banks' financial performances of the banks but some are not significant.

This study differs from previous studies in variables. Also, the time of previous studies were conducted between 2011 and 2016, while this study will conduct in 2020. Finally, previous studies did not address intellectual capital in Libyan banks.

\section{OVERVIEW OF INTELLECTUAL CAPITAL}

Intangible assets are considered as one of the most important outcomes of the science and technology revolution and the movement of global variables. Intangible assets become represent large proportions in the assets of business organizations.

From the simple analysis the intangible assets are the accumulated knowledge in the minds of human resources as a result of the actual practices of work, guidance and support from leaders and supervisors, in addition to exchanging ideas and experiences with colleagues in the work teams and follow-up of competitors, also exposure to customer demands, Also, as a result of training and development efforts in which organizations invest large sums. This accumulated knowledge is the true wealth of organizations, and it is now called Intellectual Capital, and it is also the result of continuous learning processes in organizations that have turned into educated organizations.

For this reason, the real competition has become between organizations, and even between countries, in trying to build and develop intellectual capital by all possible means, and even by trying to steal distinct intellectual elements from competitors or organizations and other countries. The primary source of intellectual capital lies in workers with experience and knowledge in organizations, and based on this, the interest in developing human resource management systems and techniques has increased in order to positively deal with these rare and valuable resources.

Based on the above, intellectual capital can be defined as an important and intangible asset in business today, especially in economies that dependent on highly technology. Intellectual capital as an intangible asset is priceless as it is managed and used to stimulate innovation and creativity, competitiveness, value creation and corporate performance [15], [16]. According to Kristandl and Bontis, intellectual capital refers to a group of intangible assets that can be used to succeed and improve an organization's image [17]. According to Sullivan the appropriate combination of values 
of intellectual capital such as knowledge, experience, financial resources, operational strategy and a good relationship with stakeholders leads to a significant improvement in organizational performance [18]. As a result of the use of intellectual capital as an important asset of global companies such as Microsoft, these companies have been able to achieve huge returns [18]. When there are immense human talents, capabilities, creativity, and limitless innovations, companies can obtain and maintain a competitive advantage. The performance of companies is affected by the concept of intellectual capital as it is consistent with the theory of resource-based vision that calls for the company to define and manage its resources (tangible or intangible) effectively to achieve more performance [19].

Also, Ross, Pike \& Fernström defined intellectual capital as all non-monetary and intangible resources that the organization controls in whole or in part and which contribute to creating the value of the organization [20]. Also, Ross, Pike \& Fernström classified intellectual capital into three components [20]:

A. Human Capital: It includes knowledge, professional skills, experience, educational level and creativity of employees. Human capital is the primary component of the process of developing intellectual capital [21]. It is inherent in people and therefore cannot be owned directly by the organization [22]. Human capital refers to what employees bring in value addition processes, and includes professional competence, employee motivation, and leadership capabilities [23]. Kavida \& Sivakumar considered human capital as a compilation of employee skills, abilities, experience, education and attitudes toward life and business [24], also all of Lings and Greenley; Sharabati, Jawad \& Bontis; Subramaniam and Youndt, all of them see that many competencies such as learning, education, experience, creativity and employee attitude, employment and training, play an important role in the development of human capital. For example, educated, experienced, trained, creative, and motivated employees can work more efficiently, so, as thus result the creation of organizational capital [25] - [27] .

B. Structural Capital: This includes innovative capital, databases, software systems, distribution networks, organizational maps, corporate culture, strategies and policies. Structural capital refers to the mechanism and structure of an organization as it helps support employees for optimal intellectual performance [28]. Edvinson \& Malone also highlighted that structural capital consists of non-human resources stored for knowledge in an organization integrated into systems, databases, and programs [22]. Moreover, Bontis, Crossan, \& Hulland indicated that an individual in an organization can never reach the fullest potential of his systems if his procedures are weak [29]. So structural capital is the outcome that extends from systems, programs, information technology, culture, innovation and development that contribute significantly to the development of the structural capital scale[30],[31], [32]. For example, welldefined structures, programs, information systems and information technologies improve employee efficiency and can create better relationships with clients, thereby enhancing the organizational value of the organization. Ahmadi, Ahmadi, and Shakeri; Allameh, Abassi, and Shokrani, Cabrita and Bontis, Hsu and Fang, and Shih, Chang and Lin, were considered that human capital is the primary component that influenced mutual capital and structural capital [32], [33] [34], [35], [3],. However, Cabrita and Bontis and Allameh Abassi, and Shokrani. that human capital indirectly affected the relationship capital through structural capital in banks and hospitals, respectively [34],[33]. According to Shih Chang and Lin, Human capital has been identified as having a direct and positive impact on relationship capital and structural capital in the service sector as well as in the banking sectors [3]. Allameh Abassi, and Shokrani. found that human capital has an impact on structural capital in services and manufacturing organizations [33]. Moreover, Shih Chang and Lin stressed that both relationship capital and structural capital have a direct and positive effect on each other. Hence, they concluded that all dimensions of intellectual capital affect each other [3].

C. Relationship Capital: It includes marketing channels, customer relations, supplier relationships, customer loyalty, government and industrial networks, brokers or partners. Mutual capital is derived from the corporation's relationship with customers, partners, shareholders, and other stakeholders that are critical to organizational performance [29]. Shih Chang and Lin defended on interconnected capital as an interface between organizations, clients, suppliers, contractors, and other partners [3]. Low also believes that relationship capital is linked to the flow of knowledge from the organization to its external environment [36]. Competencies such as customer relationship as well as customer loyalty and trust play an important role in developing relationship capital [31], [32]. For example, the higher the customer loyalty and trust, the better the relationship with the customer, which will enhance the organizational value later.

\section{RESEARCH METHODOLOGY}

This section includes following parts:

\section{A. Dependent Variables}

Financial performance is measured by the Return on Equity (ROE) and the Return on Assets (ROA) rate. Return on equity is an important financial indicator for owners. The rate of return on equity is calculated by dividing the net income before taxes by the average shareholders' equity. While the rate of return on assets reflects the efficiency of available assets in achieving profits, it is calculated by dividing the net income after taxes by the average of the total assets.

\section{B. Independent variables}

In order for these variables to be consistent with variables in previous studies, for example [37],[38] reduced their interaction with dependent variables, we include the size of the bank (measured as total assets) in the regression model as an independent variable. We also include a dummy variable among the independent variables represented by the global financial crisis, which has a value of 1 for the years 2008 and 2009, and zero other.

\section{Sample and period of study}

The sample for this study is 17 Libyan banks that comprise four commercial, five specialized banks that work in a specialized area such as agriculture, real estate, and foreign investments., and eight private banks, these banks are owned 
by people, whether they are normal or legal persons who take over the management of its affairs and will be responsible for all legal and financial activities of the bank.

This paper covers the period from 2004 to 2010. This span of time was chosen because the privatization of Libyan economy has started after United Nations and United States removed their sanctions on Libya in 2003, and 2011 was excluded because the revolution has started in Libya. In February 2011, the Libyan people revolted against Muammar Gaddafi's regime, which led to a war in Libya continued until the end of October 2011. This war has affected Libyan's economy. So, in this paper the year 2011 was excluded from this study as an exceptional year and the results that are obtained from the year 2011 will negatively affect on the full results of the study and may give an incorrect picture of the operations of Libyan banks, for this reason this paper covers the period from 2004 to 2010 . The data were obtained from the Libyan central bank statistical bulletin, Libyan stock market, and annual reports from banks.

\section{Study Method}

This study used the value-added coefficient of intellectual capital for [6], where the value-added coefficient of intellectual capital is measured as follows [11]:

$$
\mathrm{VAIC}=\mathrm{CEE}+\mathrm{HCE}+\mathrm{SCE},
$$

where:

CEE: Refers to the efficiency of the capital added value (CE), which represents the book value of the total tangible assets. CEE is calculated by dividing the added value (VA) by (CE). HCE: Indicates the efficiency of human capital in creating value. It is calculated by dividing the added value (VA) by the staff costs (HC).

SCE: Indicates the efficiency of the added value of structural capital. It is calculated by dividing the structural capital (SC) by the added value. SC is defined as the difference between (VA) and (HC).

The total added value is calculated according to the following formula:

$$
\mathrm{VA}=\mathrm{OP}+\mathrm{EC}+\mathrm{D}+\mathrm{A}
$$

Where:

$\mathrm{OP}=$ operating profit.

$\mathrm{EC}=$ Total staff operating expenses.

$\mathrm{D}=$ depreciation expense.

$\mathrm{A}=$ amortization period.

\section{E. Study models}

The study models consist of four models, where models (1) and (2) examine the interconnection between the VAIC components and the financial performance metrics (ROE \& ROA), while models (3) and (4) replace the overall IC scale with the three components of the VAIC (HCE, SCE \& CEE). Then we test all the hypotheses of the study through linear regression models to ensure the quality of data and variables as follows:

$$
\begin{aligned}
& R O E=\beta_{i}+\beta_{1} V A I C+\beta_{2} S I Z E+\beta_{3} C R I S I S+e \\
& R O A=\beta_{i}+\beta_{1} V A I C+\beta_{2} S I Z E+\beta_{3} C R I S I S+e \\
& R O E=\beta_{i}+\beta_{1} H C E+\beta_{2} S C E+\beta_{3} C E E+\beta_{4} S I Z E+ \\
& \beta_{5} C R I S I S+e
\end{aligned}
$$

$$
R O A=\beta_{i}+\beta_{1} H C E+\beta_{2} S C E+\beta_{3} C E E+\beta_{4} S I Z E+
$$$$
\beta_{5} \text { CRISIS }+e
$$

\section{F. Study hypotheses}

This study includes four hypotheses as follows:

The first hypothesis:

$H_{0}$ : There is a statistically significant relationship between the rate of return on equity and components of intellectual capital.

$H_{a}$ : There is no statistically significant relationship between the rate of return on equity and the components of intellectual capital.

The second hypothesis:

$H_{0}$ : There is a statistically significant relationship between the rate of return on assets and the components of intellectual capital.

$H_{a}$ : There is no statistically significant relationship between the rate of return on assets and the components of intellectual capital.

The third hypothesis:

$H_{0}$ : There is a statistically significant relationship between the rate of return on equity and components of the valueadded factor of intellectual capital

$H_{a}$ : There is no statistically significant relationship between the rate of return on equity and the components of the value added factor of intellectual capital.

The fourth hypothesis:

$H_{0}$ : There is a statistically significant relationship between the rate of return on assets and the components of the valueadded factor of intellectual capital.

$H_{a}$ : There is no statistically significant relationship between the rate of return on assets and the components of the value added factor of intellectual capital.

\section{EMPIRICAL RESULTS}

The components of the intellectual capital of Libyan banks were analyzed as shown in the following tables:

TABLE I: PERFORMANCE OF INTELLECTUAL CAPITAL FOR LIBYAN COMMERCIAL BANKS DURING THE PERIOD 2004-2010

\begin{tabular}{ccccc}
\hline \hline $\begin{array}{c}\text { Commercial } \\
\text { Banks }\end{array}$ & HCE & SCE & CEE & VAIC \\
\hline Mean 2004 & 7.122 & 0.819 & 1.328 & 9.268 \\
Mean 2005 & 7.470 & 0.836 & 1.660 & 9.966 \\
Mean 2006 & 6.942 & 0.831 & 1.293 & 9.065 \\
Mean 2007 & 4.938 & 0.762 & 1.313 & 7.013 \\
Mean 2008 & 6.618 & 2.907 & 1.735 & 8.979 \\
Mean 2009 & 5.573 & 0.727 & 0.786 & 7.085 \\
Mean 2010 & 10.188 & 0.776 & 1.436 & 12.400 \\
Mean 2004-2010 & 6.979 & 1.094 & 1.364 & 9.111 \\
\hline \hline
\end{tabular}

Table I Indicates that the results of the components of the value added factor of the intellectual capital of the Libyan commercial banks, where the HCE values range from 4.938 in 2007 and 10.188 in 2010. While the results of the SCE ranged between 0.727 in 2009 and 2.907 in 2008, while the results of the CEE find that the lowest value was 0.786 in 2009 and the highest value was 1.735 in 2008 . And the results of VAIC, ranged from 7.013 the lowest value to 12.4 the highest value in 2010 . 
TABLE II: PERFORMANCE OF INTELLECTUAL CAPITAL FOR LIBYAN SPECIALIZED BANKS DURING THE PERIOD 2004-2010

\begin{tabular}{ccccc}
\hline \hline Specialized Banks & HCE & SCE & CEE & VAIC \\
\hline Mean 2004 & 19.852 & 0.939 & 0.847 & 21.637 \\
Mean 2005 & 17.151 & 0.921 & 0.712 & 18.783 \\
Mean 2006 & 20.166 & 0.924 & 0.760 & 21.849 \\
Mean 2007 & 23.257 & 0.941 & 0.795 & 24.992 \\
Mean 2008 & 202.023 & 0.994 & 1.396 & 204.414 \\
Mean 2009 & 68.89 & 0.978 & 3.718 & 73.585 \\
Mean 2010 & 35.672 & 0.963 & 1.882 & 38.516 \\
Mean 2004 - 2010 & 55.287 & 0.951 & 1.444 & 57.682 \\
\hline \hline
\end{tabular}

Table II shows the results of the components of the value added factor of the intellectual capital of the Libyan specialized banks, as the HCE values ranged between 17.151 in 2005 and 202.023 in 2008. As for the results of the SCE, ranged between 0.921 in 2005 and 0.994 in 2008, and as for the results of the CEE, the lowest value was 0.712 in 2005 and the highest value was 3.718 in 2009 . The results of VAIC, ranged between 18.783 as the lowest value in 2005 and 204.414 as the highest value in 2008 .

TABLE III: PERFORMANCE OF INTELLECTUAL CAPITAL For LIBYAN PRIVATE BANKS DURING THE PERIOD 2004-2010

\begin{tabular}{ccccc}
\hline \hline Private Banks & HCE & SCE & CEE & VAIC \\
\hline Mean 2004 & 111.323 & 0.931 & 38.218 & 150.472 \\
Mean 2005 & 247.084 & 0.896 & 79.794 & 327.774 \\
Mean 2006 & 296.076 & 0.881 & 73.996 & 370.940 \\
Mean 2007 & 33.490 & 0.936 & 15.604 & 50.030 \\
Mean 2008 & 86.242 & 0.844 & 18.123 & 105.208 \\
Mean 2009 & 17.471 & 0.844 & 14.575 & 32.698 \\
Mean 2010 & 5.896 & 0.785 & 3.525 & 10.124 \\
Mean 2004 -2010 & 113.94 & 0.874 & 34.834 & 149.607 \\
\hline \hline
\end{tabular}

Table III shows the results of the components of the valueadded coefficient of the intellectual capital of Libyan private banks, where we find that the HCE values range between 5.896 as the lowest value in 2010 and 296.076 as the highest value in 2006. As for the results of the SCE, are between 0.785 in 2010 and 0.936 in 2007, while for the CCE results, the lowest value was 3.525 in 2010 , while the highest value was 79.794 in 2005 . The value of the VAIC ranged between 10.124 in 2010 and 327.774 in 2005.

TABLE IV: PERFormance OF INTELLECTUAL CAPITAL For LIByAN BANKS DURING THE PERIOD 2004-2010

\begin{tabular}{ccccc}
\hline \hline Libyan Banks & HCE & SCE & CEE & VAIC \\
\hline $\begin{array}{c}\text { Mean of } \\
\text { Commercial banks } \\
\text { 2004 - 2010 }\end{array}$ & 6.979 & 1.094 & 1.364 & 9.111 \\
$\quad \begin{array}{c}\text { Mean of } \\
\text { Specialized banks }\end{array}$ & 55.287 & 0.951 & 1.444 & 57.682 \\
2004 - 2010 & & & & \\
Mean of Private & & & & \\
banks 2004-2010 & 113.94 & 0.874 & 34.834 & 149.607 \\
Mean 2004-2010 & 58.735 & 0.973 & 12.547 & 72.133 \\
\hline \hline
\end{tabular}

Table IV Shows the results of the components of the valueadded factor of the intellectual capital of Libyan banks for the period 2004-2010, where the results show that private banks achieved the highest values for each HCE, CEE and VAIC, while the lowest values were in the share of commercial banks. On the contrary, it was the highest value of SCE the share of commercial banks, while the the lowest values were in the share of private banks.
TABLE V: REGRESSION RESULTS

\begin{tabular}{|c|c|c|c|c|}
\hline $\begin{array}{c}\text { Independent } \\
\text { Variable }\end{array}$ & Model (1) & Model (2) & Model (3) & Model (4) \\
\hline Intercept & -0.312 & 1.813 & -1.060 & 0.925 \\
\hline VAIC & $\begin{array}{c}-0.005359 \\
(-0.3844)\end{array}$ & $\begin{array}{c}0.000145^{*} \\
(1.3617)\end{array}$ & & \\
\hline $\mathrm{HCE}$ & & & $\begin{array}{c}-0.003758 \\
(-0.1042)\end{array}$ & $\begin{array}{c}0.000513^{*} \\
\text { (1.9074) }\end{array}$ \\
\hline SCE & & & $\begin{array}{c}-1.615679 \\
(-0.1057)\end{array}$ & $\begin{array}{c}0.001228 \\
(0.1076)\end{array}$ \\
\hline CEE & & & $\begin{array}{c}-0.006302 \\
(-0.0574)\end{array}$ & $\begin{array}{c}- \\
0.000122^{*} \\
(-1.4248)\end{array}$ \\
\hline Size & $\begin{array}{c}0.184596^{*} \\
(1.3425)\end{array}$ & $\begin{array}{c}0.000554^{*} \\
* * \\
(5.2947)\end{array}$ & $\begin{array}{c}0.245193 \\
(0.4138)\end{array}$ & $\begin{array}{c}0.000506 \\
(1.1439)\end{array}$ \\
\hline Crisis & $\begin{array}{c}-3.574398 \\
(-0.6911)\end{array}$ & $\begin{array}{l}-0.002035 \\
(-0.5173)\end{array}$ & $\begin{array}{c}-3.630413 \\
(- \\
0.06833)\end{array}$ & $\begin{array}{l}-0.002823 \\
(-0.1271)\end{array}$ \\
\hline Adjusted $\mathrm{R}^{2}$ & -0.018880 & -0.039076 & -0.050048 & -0.030207 \\
\hline F Value & 52.847 & 33.169 & 23.305 & 28.547 \\
\hline Sig & 0.000 & 0.000 & 0.000 & 0.000 \\
\hline
\end{tabular}

Note. $* * *, * *$ and $*$ denote significance level at the $1 \%, 5 \%$ and $10 \%$ respectively.

The VAIC has been divided into its three components and put into the regression equation to predict ROE (Model 3) as well as to predict ROA (Model 4).

Table $\mathrm{V}$ shows that there is a statistically significant relationship at $10 \%$ between the ROE and size in model (1), therefore the null hypothesis which states that (there is a statistically significant relationship between ROE and capital components Intellectual property) is accepted, while accepting the first alternative hypothesis for the rest of the components of intellectual capital.

Also, there is a statistically significant relationship at the level of $1 \%$ between the ROA and the size in Form (2), therefore, the null hypothesis which states that (there is a statistically significant relationship between the ROA and components of intellectual capital) is accepted, on the other wise, The second alternative hypothesis for the rest of the components of intellectual capital is accepted.

As for model (3), there is no statistically significant relationship between the ROE and the components of the value-added factor of intellectual capital. Accordingly, the third null hypothesis is rejected and the third alternative hypothesis is accepted, which states (There is no statistically significant relationship between the ROE and any component of the VAIC).

Whereas, it is evident from model (4) that, there is a statistically significant relationship at the level of 5\% between the ROA and HCE, also, there is a statistically significant relationship at the level of $10 \%$ between the ROA and CEE. So, we have to accept the fourth null hypothesis, which states that (there is a statistically significant relationship between the ROA and the components of the VAIC). And the fourth alternative hypothesis is accepted for the rest of the components of the VAIC, which states that (there is no statistically significant relationship between the ROA and components of the VAIC).

These results are consistent with the findings of Mehralian et al. in Iran, and Ku Ismail and Abdul Karem in Bahrain, as 
well as the findings of Firer and Williams in South Africa,[39],[40], [41] This study also showed that tangible assets are the main source of financial performance in Libyan banks. The results, which were reached in this study, showed that there is no impact of the global financial crisis on the indicators of the financial performance of Libyan banks, and the reason why the global crisis may not affect Libyan banks may be due to the policies adopted by the Central Bank and the Libyan government to limit the impact of this the crisis.

\section{CONCLUSION}

This study examines intellectual capital (IC) performance of Libyan banks during the period from 2004 to 2010, using value-added intellectual coefficient (VAIC) methodology, and investigates the impact of IC on financial performance.

The empirical findings suggests that during the period of study, The results showed that the components of the intellectual capital of the Libyan banks for the period from 2004 to 2010 showed that the private banks achieved the highest values for HCE, CEE and VAIC, while the lowest values were in the share of commercial banks. On the contrary, the highest value of the SCE was in the share of commercial banks, while the value was the lowest of the share of private banks. Also, the empirical finding suggests that the four regression models showed acceptance of the null hypothesis for some components of intellectual capital as well as for some components of the value-added factor of intellectual capital in models (1), (2) and (4), while the null hypothesis was rejected in model (3) and acceptance of the alternative hypothesis. Also, the comparison between (HCE) and (CEE) indicates the ability of Libyan banks to create value based on the capital used (CE) and also on human capital (HC). This result is not surprising because the banking sector is a services sector, as customer services depend heavily on human capital. And, the findings showed that banks that could use (HC) better are more likely to stay. The results also indicated that there is an urgent need to develop the efficiency of structural capital (SC) as an important component of intellectual capital.

This study submits some recommendations. First, Libyan banks' interest in the components of intellectual capital, because this will increase the efficiency of the performance of these banks. Second, those banks identify some people and train them to provide added value to human capital, given that continuous training is an important and vital tool for the performance of employees and managers. Third, Libyan banks are supposed to add a job or position to manage intellectual capital in their organizational structures to help structure relevant strategies and policies on how to obtain, benefit from and develop the best resources for intellectual capital. Finally, the findings can also assist policy makers in Libyan banks in formulating and implementing policies to create a flexible banking sector.

\section{ACKNOWLEDGMENT}

Any attempt at any level can't be satisfactorily completed without the support of my University (University of Benghazi).

\section{REFERENCES}

[1] P. O. Pablos, "Evidence of Intellectual Capital Measurement From Asia, Europe and Middle East," Journal of Intellectual Capital, vol. 3, no 3, pp. 287-302, 2002.

[2] D. Maditinos, D. Chatzoudes, C. Tsairidis, and G. Theriou, "The Impact of Intellectual Capital on Firms' Market Value and Financial Performance," Journal of Intellectual Capital, vol. 12, no. 1, pp. 132 $51,2011$.

[3] K. Shih, C. Chang, and B. Lin, B. "Assessing Knowledge Creation and Intellectual Capital in Banking Industry," Journal of Intellectual Capital, vol. 11, no. 1, pp. 74-89, 2010.

[4] B. R. Ahuja, and N. L. Ahuja, "Intellectual Capital Approach to Performance Evaluation: A Case Study of The Banking Sector in India," International Research Journal of Finance \& Economics, vol. 93, pp. 110-122, 2012.

[5] P. C. Goh, "Intellectual Capital Performance of Commercial Banks in Malaysia," Journal of Intellectual Capital, vol. 6, no. 3, pp. 385-396, 2005.

[6] A. Pulic. (1998). Measuring the Performance of Intellectual Potential in Knowledge Economy. [Online]. Available: http://www.measuring ip.at/Opapers/Pulic/Vaictxt.vaictxt.html.

[7] S. A. Mohammed, "Finance -Growth Nexus in Sudan: Empirical Assessment Based on an Application of the Autoregressive Distributed Lag (ARDL) Model," Arab Planning. Institute in Kuwait, API/WPS 0803, 2002.

[8] A. N. Berger, and R. DeYoung, "Problem Loans and Cost Efficiency in Commercial Banks," Journal of Banking and Finance, vol. 21, 1997.

[9] Panorama report. (2008). Modernizing the Banking Sector and Investing Globally, Libya. [Online]. Available: http://www.panoramareportsltd.com/pdflibya.pdf.

[10] F. Abdulsalam, H. Al-Qaheri, and R. Al- Khayyat, "The Intellectual Capital Performance of Kuwait Banks: An Application of VAIC Model," Scientific Research, vol. 3, pp. 88 - 96, 2011.

[11] D. F. Abdullah, and S. Sofian, "The Relationship between Intellectual Capital and Corporate Performance," Procedia - Social and Behavioral Sciences, vol. 40, pp. 537 - 541, 2012.

[12] M. A. Al-Musali, and K. N. Ismail, "Intellectual Capital and Its Effect on Financial Performance of Banks: Evidence From Saudi Arabia," Procedia - Social and Behavioral Sciences, vol. 164, pp. 201 - 207, 2014.

[13] J. Arifin "Corporate Governance and Intellectual Capital on Financial Performance of Bank Sector Companies: Indonesia Stock Exchange 2008-2012," Journal of Administrative Sciences and Policy Studies, vol. 4, no. 1, pp. $61-82,2016$.

[14] U. L. Onyekwelu, J. I. Okoh and F. C. Iyidiobi, " Effect of Intellectual Capital on Financial Performance of Banks in Nigeria," European Journal of Accounting, Auditing and Finance Research, vol. 5, no. 2, pp. $28-57,2017$.

[15] N. Bontis, W. C. K. Chua, and S. Richardson, "Intellectual Capital and Business Performance in Malaysian Industries,"Journal of Intellectual Capital, vol. 1, no. 1,85-100, 2000.

[16] M. Tayles, R. H. Pike, and S. Sofian, "Intellectual Capital, Management Accounting Practices and Corporate Performance: Perceptions of Managers," Accounting, Auditing \& Accountability Journal, vol. 20, no. 4, pp. 522-548, 2007.

[17] G. Kristandl, and N. Bontis, N. "Constructing a Definition for Intangibles Using the Resource Based View of the Firm," Management Decision, vol. 45, no. 9, pp. 1510-1524, 2007.

[18] P. H. Sullivan, "Profiting from Intellectual Capital," Journal of Knowledge Managemen, vol. 3, no. 2, pp. 132-142, 1999.

[19] R. A. Raja Adzrin, A. N. Abu Thahir, and M. S. Maisarah, "Value Creation Strategy for Sustainability," Accountants Today, vol. 22, no. 1, pp. 12-31, 2009.

[20] G. Roos, S. Pike, and L. Fernström, Managing Intellectual Capital in Practice, New York, NY: Butterworth-Heinemann, 2005.

[21] C. Yang, and C. Lin, "Does Intellectual Capital Mediate the Relationship between HRM and Organizational Performance? Perspective of a Healthcare Industry in Taiwan," The International Journal of Human Resource Management, vol. 2, no. 9, pp. 19651984, 2009.

[22] L. Edvinson, and M. Malone, Intellectual Capital: Realizing Your Company's True Value by Finding Its Hidden Roots, New York, NY: Harper Business, 1997.

[23] S. Halim, "Statistical Analysis on the Intellectual Capital Statement," Journal of Intellectual Capital, vol. 11, no. 1, pp. 61-73, 2010.

[24] V. Kavida, and Sivakumar, "Intellectual Capital: A Strategic Management Perspective," The IUP Journal of Knowledge Management, vol. 7, no. 6, pp. 55-69, 2009. 
[25] I. Lings, and G. Greenley, "Measuring Internal Market Orientation," Journal of Service Research, vol. 7, no. 3, pp. 290-305, 2005.

[26] A. Sharabati, S. Jawad, and N. Bontis, "Intellectual Capital and Business Performance in the Pharmaceutical Sector of Jordan," Management Decision, vol. 48, no. 1, pp. 105-131, 2010.

[27] M. Subramaniam, and M. Youndt, "The Influence of Intellectual Capital on the Types of Innovative Capabilities," Academy of Management Journal, vol. 48, no. 3, pp. 450-463, 2005.

[28] L. Bollen, P. Vergauwen, and S. Schnieders, "Linking Intellectua Capital and Intellectual Property to Company Performance," Management Decision, vol. 43, no. 9, pp. 1161-1185, 2005.

[29] N. Bontis, M. Crossan, and J. Hulland, "Managing an Organizational Learning System by Aligning Stocks and Flows," Journal of Management Studies, vol. 39, no. 4, pp. 439-469, 2002.

[30] J. Choudhary, "Performance Impact of Intellectual Capital: A Study of Indian IT Sector," International Journal of Business and Management, vol. 5, no. 9, pp. 72-80, 2010.

[31] R. Isaac, I. Herremans, and T. Kline, "Intellectual Capital Management Enablers: A Structural Equation Modeling Analysis," Journal of Business Ethics, vol. 93, no. 3, pp. 373-391, 2010.

[32] A. Ahmadi, F. Ahmadi, and S. Shakeri, "The Survey of Relationship between Intellectual Capital (IC) and Performance (OP) Within the National Iranian South Oil Company," Interdisciplinary Journal of Contemporary Research in Business, vol. 3, no. 5, pp. 1-12, 2011.

[33] S. Allameh, S. Abbasi, and S. Shokrani, "The Mediating Role of Organisational Learning Capability between Intellectual Capital and Job Satisfaction," European Journal of Social Sciences, vol. 17, no. 1, pp. 1-12, 2010.

[34] M. Cabrita, and N. Bontis, "Intellectual Capital and Business Performance in the Portuguese Banking Industry," International Journal of Technology Management, vol. 43, no. 1-3, pp. 1-26, 2008.

[35] Y. Hsu, and W. Fang, "Intellectual Capital and New Product Development Performance: The Mediating Role of Organizational Learning Capability," Technological Forecasting \& Social Change. vol. 76, no. 5, pp. 664 677, 2009.

[36] J. Low, "The Value Creation Index," Journal of Intellectual Capital, vol. 1, no. 3, pp. 252-262, 2000.

[37] K. H. Chan, "Impact of Intellectual Capital on Organizational Performance: An Empirical Study of Companies in the Hang Seng Index," The learning Organization, vol. 16, no. 1, pp. 4-21, 2009

[38] H. J. Shiu, "The Application of the Value Added Intellectual Coefficient to Measure Corporate Performance: Evidence from Technological Firms," International Journal of Management, vol. 23 , no. 2, pp. 356-65, 2006

[39] G. Mehralian, A. Rajabzadeh, M. R. Sadeh, and H. R. Rasekh, "Intellectual Capital and Corporate Performance in Iranian Pharmaceutical Industry," Journal of Intellectual Capital, vol. 13, no. 1, pp. 138-158, 2012.

[40] K. N. I. Ku Ismail, and M. Abdul Karem, "Intellectual Capital and the Financial Performance of Banks in Bahrain," Journal of Business Management and Accounting, vol. 1, no. 1, pp. 63-77, 2011.

[41] S. Firer, and S. M. Williams, "Intellectual Capital and Traditional Measures of Corporate Performance," Journal of Intellectual Capital, vol. 4, no. 3, pp. 348-360, 2003.

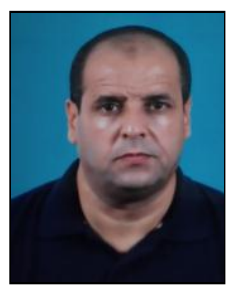

Khalad M. S. Alrafadi completed his: Bachelor Degree in Civil Engineering- Grayounis University- Benghazi, Libya in 1996, Bachelor Degree in Business Management- Grayounis University- Benghazi, Libya in 2000, Bachelor Degree in Accounting- Grayounis UniversityBenghazi, Libya in 2001, Master Degree in Business Management - Garyounis University Benghazi, Libya in 2005. PhD Degree in Business Management - Faculty of Business and Management - Universiti Teknologi MARA, Malaysia. Currently, Khalad is a lecturer at faculty of economic, University of Benghazi. 